\title{
A long and winding road: defining the biological role and clinical importance of paraoxonases
}

\author{
Richard W. James* \\ Clinical Diabetes Unit, Service of Endocrinology, \\ Diabetes and Nutrition, University Hospital, Geneva, \\ Switzerland
}

\begin{abstract}
Paraoxonase-1 (PON1) is an enzyme belonging to a three-member gene family, each of which is highly conserved in mammalian evolution. Whilst there is consensus that the paraoxonase family members have a general protective influence, their precise biological role has remained elusive. A toxicological role, protecting from environmental poisoning by organophosphate derivatives, drove much of the earlier work on the enzymes. More recently, clinical interest has focused on a protective role in vascular disease via a hypothesised impact on lipoprotein lipid oxidation. Recent confirmation that the primary activity of the paraoxonases is that of a lactonase considerably expands the potential sources of biological substrates for the enzyme. Studies on such substrates may shed further light on different mechanisms by which paraoxonases beneficially influence atherosclerosis, as well as defining possible roles in limiting bacterial infection and in innate immunity.

Clin Chem Lab Med 2006;44:1052-9.
\end{abstract}

Keywords: high-density lipoproteins; innate immunity; lactonase; oxidative stress; quorum quenching; toxicology; vascular disease.

\section{Introduction}

Clinical interest in the serum enzyme paraoxonase-1 (PON1) has spanned over half a century without arriving at a consensus on its biological role. Nevertheless, the enzyme is something of a growth industry with respect to the clinical attention it continues to attract. A number of factors have contributed to the present uncertainty about its role, in particular the promiscuous range of substrates hydrolysed by the enzyme. Very recent developments, which have identified the primary substrate group for PON1, should significantly advance our understanding of its biological function.

*Corresponding author: Prof. R.W. James, Clinical Diabetes Unit, Service of Endocrinology, Diabetes and Nutrition, University Hospital, 24, rue Micheli-du-Crest,

1211 Geneva 14, Switzerland

Phone: +41-22-3729304, Fax: +41-22-3729309,

E-mail: richard.james@hcuge.ch
This review looks at the past, present and future of PON1 in terms of its emergence as a focus of somewhat diverse clinical interests.

\section{The paraoxonase gene family}

The paraoxonase gene family comprises three genes (PON2, PON3, PON1) closely aligned in that order on human chromosome 7 (1). There is substantial $(60-80 \%)$ sequence homology at the gene and protein levels between the three PONs within a species, and between corresponding PON members across species. The family has arisen by gene duplication, with $P O N 2$ being the ancestral gene, followed by the emergence of PON3 then PON1.

Initial analyses indicated no homology with known enzyme gene families, which could hint at the origins and function of the PON family. Subsequent identification of sequence similarities with lactonases, initially reported for a fungal lactonase (2), has led to proposals of an evolutionary link between the two types of enzyme. This hypothesis has been strengthened by recent reports concerning the substrate preferences of PONs (see below).

The human $P O N$ genes are differentially expressed $(1,3,4)$. PON1 expression is largely confined to the liver, as is $P O N 3$. Both enzymes can be released into the circulation, although PON1 activity predominates in man. Within serum, PON1 circulates tightly associated with a subclass of lipoproteins, high-density lipoprotein (HDL) (5). PON2 is more ubiquitously expressed and does not appear to be released from cells. It can be located in the cell membrane, with its active site exposed to the external milieu. PON1 enjoys a similar orientation in the hepatocyte membrane prior to its secretion and association with HDL (6).

This overview predominantly focuses on PON1, for which clinical interest has been most ardent in recent years.

\section{The past}

The terminology "past" does not imply that the preceding focus of interest in PON1 is no longer or of less clinical relevance. It should be taken to reflect where attention was particularly centred in the continuum of attempts to understand the biological role of the enzyme. The period lasted from the discovery of PON enzyme activity in 1946 to the early 1990s. Clinical and biological interest was directed to the toxi- 
cological associations of the enzyme, notably with reference to environmental and military implications.

\section{Substrate specificity and biological role}

PON-type activity was first described in 1946 as the capacity of tissues to hydrolyse organophosphate (OP) derivatives (7). This esterase activity was characterised in greater detail in mammalian sera (8), for which two subclasses were defined: A-esterases, encompassing PON, which are not inhibited by OP compounds and are thus capable of neutralising them; and B-esterases, exemplified by acetylcholinesterase, which are inactivated by such derivatives.

The highly toxic derivatives hydrolysed by the enzyme are largely triesters of phosphoric acid (9) (Figure 1). These include insecticides such as parathion (metabolised to paraoxon, which is neutralised by PON1) and diazinon (metabolised to diazoxon), as well as nerve agents (sarin, soman). The enzyme is also able to hydrolyse aromatic esters such as phenylacetate and naphthyl acetate (10). Paraoxon and phenylacetate are the two substrates most commonly used to monitor activity of the enzyme, which can give rise to a certain degree of confusion. Hydrolysis of paraoxon (PON activity) gave rise to the name of the enzyme; hydrolysis of phenylacetate is referred to as arylesterase activity. There was considerable debate as to whether the two activities resided in the same or different proteins. The latter was, at one point, taken to be the case (11), although this had been contested (10). The issue was definitively resolved by cloning of the gene (see below), whereby the activities were shown to reside within the same protein $(12,13)$.

A second area where confusion can arise relates to activity polymorphism. It had been well established that serum activity with paraoxon displayed a bimodal or trimodal distribution in populations, with sera showing low, intermediate and high activity (10). Con-

A<smiles>[X]OP([O])([O])=O</smiles>

Paraoxon $\mathrm{a}, \mathrm{b}=\mathrm{C}_{2} \mathrm{H}_{5} \mathrm{O}$ $\mathrm{c}={ }^{+} \mathrm{NO}_{2}$

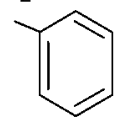

$X$, leaving group

Sarin

$\mathrm{a}=\mathrm{CH}_{3}$

$\mathrm{b}=\mathrm{CH}\left(\mathrm{CH}_{3}\right)_{2} \mathrm{O}$

$\mathrm{c}=\mathrm{i}-\mathrm{C}_{3} \mathrm{H}_{7} \mathrm{O}$

B

Lactone

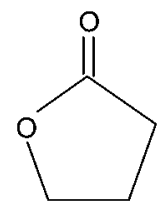

Homocysteine thiolactone

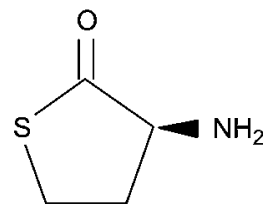

Figure 1 Basic structure of phosphoric acid triesters and lactones. versely, no such activity distribution was evident for phenylacetate. The situation was also resolved by cloning of the gene and the identification of a single nucleotide polymorphism (SNP) at position 192. A glutamine $(Q)$ to arginine $(R)$ exchange gives rise to alleles with low (Q) and high (R) hydrolytic activity towards paraoxon $(12,13)$. However, this is not a general rule for the activity of the alleles towards substrates. As indicated above, phenylacetate hydrolysis does not show evident hydrolysis rate differences between $\mathrm{Q}$ and $\mathrm{R}$ alleles, whilst other substrates [diazoxin, sarin, (14)] show a higher hydrolytic rate with the $\mathrm{Q}$ than the $\mathrm{R}$ allele.

During this period, little progress was made in identifying the physiological substrate of PON1 as a pointer to its function. The xenobiotic nature of available substrates gave few clues and was compounded by the relaxed substrate specificity and inconsistent effects of the 192 polymorphism on activities of available substrates. An early suggestion that there may be a link to carboxylesterases (15) was scotched by cloning of the PON1 gene, which showed no homology with such enzymes.

\section{Clinical interest}

Clinical interest in PON1 during this period was driven by its potential to neutralise environmental poisons that block acetylcholinesterase. The toxic effects of these compounds, arising from the inability of inactivated acetylcholinesterase to eliminate acetylcholine, cause over-stimulation of nicotinic and muscarinic receptors in the central and peripheral nervous systems, leading to the cholinergic syndrome (16). Organophosphate poisoning has also been associated with delayed polyneuropathy, which involves inhibition of a different central nervous system esterase (17).

The short resumé above implies that PON1 activity is a determinant of susceptibility to OP poisoning. Several studies supported this hypothesis. Animal sensitivity to OPs correlates with levels of serum PON1. Thus, birds, which are deficient in PON1, are more susceptible to such poisons than mammals (18). Conversely, rabbits have higher levels of PON activity than rats and are more resistant than rats to OP poisoning (9). Injection of rats (19) and mice (20) with partially purified $\mathrm{PON}$ increased their resistance to OPs.

\section{Resumé}

The period until the early 1990s was dominated and driven by the clinical potential of the enzyme to limit OP poisoning, whether of an agricultural or military nature. Contemporary data largely support this potential, and it was subsequently confirmed by later use of transgenic animals (see below). Very little progress was made in identifying physiological substrates and defining the biological role of PON1. The consensus was for a generally protective role with wide substrate specificity. 


\section{The present}

This period began in the early 1990s with two events that radically changed clinical considerations about PON and opened new avenues of research. The first event was the hypothesis advanced by Mackness and colleagues that PON1 may be able to prevent or limit oxidation of low-density lipoprotein (LDL) lipids (21). As the oxidative modification hypothesis (22) is a central tenet of the relationship between LDL and atherosclerosis, the proposal thrust PON into the clinical arena that is the principal cause of mortality and morbidity in developed countries. The second event was the cloning of the PON1 gene $(12,13)$, opening the possibility of more sophisticated structure-function studies, analysis of the enzyme active site, availability of highly pure protein, and the development of animal models. Clinical emphasis gradually shifted to the involvement of PON in vascular disease, without losing sight of its toxicological links.

\section{Substrate specificity and biological role}

Oxidation of LDL is the principal modification of this lipoprotein species that renders it atherogenic and capable of promoting atherosclerotic disease. The hypothesised ability of PON to prevent or limit oxidation prompted attempts to identify potential substrates in the form of oxidised lipids. Several candidates have been proposed, as indicated in Table 1. These arose essentially from single publications, with no confirmation or further examination in subsequent studies. This reflects in part the difficulties and technical requirements needed to identify and analyse such oxidised lipids. No consensus substrate emerges from the list, although PON1 may be expected to have broad substrate specificity in this respect. Another feature of this short list is the presence of PON products, notably lysophospholipids, that are biologically active, with both physiological and pathophysiological effects (26). In this respect, the wellestablished association of serum PON1 with HDL may be of importance. HDLs carry a number of components that protect against oxidative stress (27). A synergistic interaction between the components within HDL may be necessary to counter the variety of lipid products that can be generated by lipoprotein oxidation, as proposed by Ahmed et al. (28).

The difficulties in identifying and analysing individual lipid oxidation products as potential PON1 substrates should be underlined. The type of oxidation process used and the length of exposure to oxidation can modify the cocktail of oxidation end-products

Table 1 Oxidised lipids postulated as substrates for paraoxonase.

\begin{tabular}{ll}
\hline Lipid & Reference \\
\hline Cholesterol linoleate hydroperoxide & $(23)$ \\
Oxidised 1-palmitoyl-2-arachidonoyl-sn- & $(24)$ \\
glycero-3-phosphorylcholine (Ox-PAPC) \\
Oxidised linoleic acid
\end{tabular}

(29). The oxidation products are not stable and, as well as promoting further oxidation, degrade into other products. This necessitates a certain degree of specialisation and expertise in order to analyse such molecules.

Thus, for a number of reasons, there has been little progress in identifying oxidised lipids as substrates for PON. In their absence, the bulk argument supporting oxidised lipids as substrates for PON, and indeed a role for the enzyme in suppressing lipoprotein oxidation, comes from more general measures of lipid oxidation. The degree of lipid oxidation can be quantified in terms of lipoperoxides, thiobarbituric acid-reactive substances (TBARS) and conjugated dienes (30). A number of studies carried out by a variety of independent groups show an inverse relationship between the level of oxidised lipid products and PON1 activity in vitro $(23,25,31-33)$. Some studies have also shown an inverse relationship between the two parameters in vivo $(34,35)$. Furthermore, PON1deficient HDL from PON1 knockout mice was unable to prevent oxidation of LDL, but the activity could be restored by adding purified PON1 (36). The consequences of modulating the PON1 complement of $\mathrm{HDL}$, and thus lipoprotein oxidation, have been linked to the pathological characteristics of oxidised lipoproteins. HDL lacking PON1 is unable to prevent LDL acquiring pro-atherogenic characteristics, notably stimulation of monocyte migration and up-regulation of monocyte chemotactic protein-1 $(37,38)$. Indeed, loss of PON1 can induce an important change in HDL as it veers from an anti-inflammatory to a pro-inflammatory complex (37), which fundamentally alters its association with the atherosclerotic process.

In the continued absence of a defined physiological substrate for PON1, paraoxon (PON activity) and phenylacetate (arylesterase activity) remain the principal means of monitoring enzyme activity. The question thus arises as to what extent they mirror the anti-oxidant activity of the enzyme. A number of studies have reported positive correlations between activity with these substrates and the anti-oxidant activity of PON1 $(23,25,33)$. Others have shown a certain divergence of the two activities $(39,40)$. Recent studies appear to have clarified the issue. Using recombinant PON with different mutations of the region encompassing the active site, it was shown that arylesterase activity best reflected the anti-oxidant function, even though it was not directly responsible for it (41). In contrast, paraoxon hydrolysis was a relatively poor substitute for the anti-oxidant activity. This suggests that phenylacetate hydrolysis can be used as a surrogate for the anti-oxidant capacity, at least until a viable, widely applicable assay becomes available for lactonase activity (see below).

\section{Clinical interest}

The last 15 years have seen the possible protective role of PON1 against atherosclerotic disease dominate clinical interest in the enzyme for several convergent reasons. As mentioned previously, LDL oxidation has been one of the principal driving forces 
of atherosclerosis research. Equally important, the tight association of PON1 with HDL locates it within the lipoprotein complex that exerts a powerful, negative influence on the risk of vascular disease. Finally, HDL has become a major therapeutic target for modulating the risk of vascular disease.

The strongest evidence for a protective role of PON1 in cardiovascular disease comes from animal studies. PON1 knockout mice show a significant increase in the extent of atherosclerotic lesion development (36), even in transgenic models (apoE:PON1 double knockout) in which the prevalence of atherosclerosis is equivalent to that observed in man (42). Conversely, mice over-expressing PON1 are better protected against lesion development (43). Confirmation of these conclusions has been recently furnished in independent models. Kupfer (macrophage) cell expression of PON1 significantly reduced lesion formation in cholesterol-fed mice (44). The development of atherosclerosis was also retarded in a mouse model of the metabolic syndrome in which PON1 was over-expressed (35). As with the earlier studies, the PON1-mediated anti-oxidant activity of HDL was a negative correlate of lesion formation.

As regards data from studies of human populations, these are consistent with a role for PON1 in vascular disease, without providing unambiguous proof. One prospective study has shown that reduced serum PON1 activity was an independent predictor of coronary disease (45). It was, however, based on paraoxon hydrolysis and may require re-appraisal in light of suggestions that such activity is not a reliable surrogate for PON anti-oxidant activity (41). A wide range of other studies has shown significantly lower serum PON activity in patients with confirmed vascular disease or in high-risk populations. These include patients with coronary disease (46-48), diabetes (49-52), familial hypercholesterolaemia $(53,54)$, the metabolic syndrome $(55,56)$, and smokers $(52,57$, $58)$. In the context of some uncertainty about the value of enzyme activities as surrogates for anti-oxidant function, analysis of serum PON peptide mass would seem an appropriate alternative. It has occasionally been analysed and shown to be reduced in high-risk patients $(47,48)$.

PON1 activity is itself sensitive to the oxidative stress status, which can lead to enzyme inactivation (59). This may be a contributory factor to lower serum PON1 in the clinical states outlined above, as all are associated with increased oxidative stress. Conversely, factors that diminish oxidation appear to improve serum levels of the enzyme. Thus, positive dietary effects on serum PON1 activity have been reported with vitamin intake (60) and pomegranate juice consumption (linked to its anti-oxidant content) (61). Postprandial hypertriglyceridaemia was found to transiently modulate serum PON1 activity and concentration (62), which may reflect the influence of the triglyceride-rich lipoproteins on PON1 metabolism (63).

Serum activity of the enzyme may also be amenable to pharmacological manipulation. Statins, the drug class most widely used to lower serum LDL, are associated with improved serum concentrations and activities of PON1 (64). A molecular basis for this effect has been described $(64,65)$, suggesting that it is not merely a side effect of reductions in LDL and possible removal of oxidised lipids (which can inhibit enzyme activity).

The toxicological role of PON continues to attract attention, reflecting growing public concern with environmental impacts on health. It was suggested that children may be more susceptible to environmental poisons owing to lower overall metabolic activity and perhaps reduced expression of PON activity $(66,67)$. Other clinical consequences of OP poisoning and modified cholinergic function were also proposed, including an impact on Parkinson's disease (68) and anxiety (69). These and similar studies require further investigation, but they reflect the fact that the clinical consequences of OP poisoning are potentially very extensive (70). The advent of transgenic mice that over- and under-express PON1 provided more solid support for the hypothesis mentioned above on OP sensitivity. PON1 knockout mice were more sensitive to OP poisoning, where the $\mathrm{Q}$ and $\mathrm{R} 192$ alleles differed in their protective effects (20). The higher the hydrolytic activity of the allele, the greater is its protective effect, underlining the metabolic importance of high hydrolytic capacity. Interestingly, PON1 knockout mice showed little change in susceptibility to paraoxon poisoning compared to wild-type mice. Conversely, there were important differences in susceptibility to diazoxon. The explanation appears to lie with the far greater hydrolytic rate of PON1 towards diazoxon than paraoxon, even though the enzyme neutralises paraoxon.

\section{Resumé}

There are persuasive arguments from animal studies to support the hypothesis of a role for PON1 in atherosclerotic disease. Data from human studies are largely consistent with the hypothesis. In vitro studies show a negative correlation between PON1 activity/ concentration and lipoprotein oxidation, although not consistently, whilst in vivo a modulated capacity to limit lipoprotein oxidation is a strong correlate of altered serum PON1 levels. Several putative oxidised lipids have been advanced as substrates for PON1, but the absence of a consensus substrate remains a limitation of the hypothesised role of the enzyme in protecting lipids from oxidation.

\section{The future}

Studies over the last few years have provided firm support for the contention that the basic enzyme activity of PON1 is that of a lactonase, thus identifying the principle substrate group as lactones and their derivatives. This should largely condition the future direction of research concerning the PON family function. It opens new perspectives for the enzyme, which 
complement previous considerations of its biological role and clinical relevance.

\section{Substrate specificity and biological role}

Sequence similarities revealed by genetic analyses gave the first indications of links between the PON family and lactonases (2). It was followed by publications demonstrating that PON1 was capable of hydrolysing lactone-based substrates (71, 72). Detailed analyses by Khersonsky and Tawfik (73) and Dragonov et al. (74) confirmed and affirmed lactonase activity of the different PON family members. Both groups analysed a wide selection of substrates representing different hydrolytic activities, and concluded that lactonase (Figure 1B) was the principal ancestral enzyme activity. In this context, the more limited range of substrates hydrolysed by PON2, which focuses on lactones, may reflect the core activity of the PON family, given that PON2 is the ancestral gene, whilst PON1 and PON3 enzymes would have evolved a wider range of substrate specificities (74).

The designation of lactones as the principal substrates for PON opens a fascinating diversity of potential physiological substrates. These are outlined in Table 2. The list is restricted at present to those molecules that have already been shown to be substrates for PON1.

\section{Clinical interest}

The potential clinical relevance of lactonase activity of PON enzymes is summarised in Table 2. Four areas appear of notable interest. Links with vascular disease via lipid oxidation still figure prominently via 5hydroxy-eicosatetraenoic acid 1,5-lactone (5-HETEL) and 4-hydroxy-docosahexaenoic acid (4-HDoHE), which are derivatives of the oxidised fatty acids arachidonic and docosahexaenoic acid, respectively. These, and other structurally related derivatives, notably lipoxins (75), can have potent biological activities, particularly implicating the inflammatory response. The latter is also of particular relevance to atherosclerosis, which is now considered to be a chronic inflammatory disease (76). Identification of such substrates that are metabolised by PON would strengthen the role of PON as a modulator of the inflammatory response. The latter is already implicit in the ability of PON to limit lipoprotein oxidation, as oxidised lipids provoke a powerful inflammatory reaction (77).
Links to vascular disease are also inherent to the homocysteine thiolactonase activity of human sera first reported by Jakubowski (72), who showed that it resided within HDL and specifically PON1. Homocysteine is a strong independent risk factor for atherosclerosis (78). It can induce chemical modification of peptides, a process in which homocysteine thiolactone has been implicated (79). Such modifications can alter peptide function, as well as rendering the peptide immunogenic and susceptible to homocysteineinduced oxidative stress (80). Thiolactonase activity thus offers a protective mechanism against peptide modifications that could promote atherogenic changes in lipoproteins, amongst other blood components.

Homoserine lactones (HSLs) are an important family of signalling factors in bacterial biology. They provide a communications network between bacteria, termed quorum sensing, that allows coordinated regulation of gene expression to achieve a number of objectives (81). It facilitates, for example, bacterial infection and colonisation. The ability to neutralise these signalling factors would thus represent a protective mechanism against bacterial infection. Recent studies have clearly established that the PON family can hydrolyse and neutralise HSLs $(82,83)$. In this respect, PON2 appears to be more active than PON1 (74), perhaps reflecting the ancestral function of PON. Incidentally, the cell membrane location of PON2 would be especially suitable for resisting bacterial colonisation of tissue surfaces. Of particular interest is the suggestion that the ability to inactivate HSLs may be a feature of the innate immune system (82), implying that the PON family may have an important evolutionary role. On a speculative level, such activity may also link PON1 to atherosclerosis, as bacterial infection has been proposed as an independent risk factor for vascular disease (84).

Finally, the lactonase activity of PON1 provides the basis for a role in drug metabolism. The enzyme has been shown to inactivate lactone derivatives of glucocorticoids (85). This has been exploited to limit unwanted side-effects of such drugs during topical application by neutralising any drug diffusing outside the area under treatment. The converse use of PON1 to activate prodrugs has also been exploited. This is the case for the antibiotic prulifloxacin, which is given in an inactive form and activated by serum PON1 (86). The statin drugs lovastatin and simvastatin are also activated by PON1 (87). This has pharmacogenetic implications for patients treated with such drugs,

Table 2 Lactone substrates for paraoxonase.

\begin{tabular}{ll}
\hline Substrate group & Substrate \\
\hline Oxidised lipid derivatives & $\begin{array}{l}\text { 5-hydroxy-eicosatetraenoic acid 1,5-lactone (5-HETEL) } \\
\text { 4-hydroxy-docosahexaenoic acid (4-HDoHE) } \\
\text { Drug metabolism }\end{array}$ \\
$\begin{array}{l}\text { Simvastatin, lovastatin } \\
\text { Spironolactone }\end{array}$ \\
Prulifloxacin \\
Glucocorticoid $\gamma$-lactones \\
Amino acid derivatives & Homocysteine thiolactone \\
Bacterial signalling molecules & Homoserine lactones \\
\hline
\end{tabular}


although, to date, there are no indications of any interaction between the enzyme and these drugs that has influenced their use in patients.

\section{Resumé}

The identification of lactonase activity as the principal function of the PON family has widened the number of potential substrates and, thus, the clinical relevance of the enzymes. Several biologically relevant lactone substrates for PON1 have already been identified. These and other substrates need to be further investigated and their true clinical impact defined. The latter point should become a focus of attention for PON1 research in the next decade. An association with vascular disease still remains a strong candidate for the clinical impact of the enzyme, which accords with available data. This relationship would be strengthened if stronger ties with the inflammatory response were also revealed. Finally, the ability to modulate bacterial virulence offers one appealing explanation for the evolutionary stability of the PON gene family, as it is likely to reflect a primitive but continuing protective function. Furthermore, it opens an avenue of research for a role of the PON proteins in innate immunity.

\section{Conclusions}

Whilst identification of a precise biological role for the PON family remains a primary objective, their designation as lactonases reinforces early indications of a general and widespread protective function. In this context, identification of a single, or a narrow range of PON substrates may be too blinkered a view of their function. Vascular disease has been the particular focus of the protective role in recent years, but this could be extended to other areas of clinical interest in the future. It will be particularly interesting to examine if the association of PON1 with HDL represents adaptation of a previously static protective function to one of greater mobility and versatility.

\section{Acknowledgements}

The author gratefully acknowledges the support of the Swiss National Research Foundation for studies in his laboratory that are referred to in this review.

\section{References}

1. Primo-Parmo SL, Sorenson RC, Teiber J, La Du BN. The human serum paraoxonase/arylesterase gene (PON1) is one member of a multigene family. Genomics 1996; 33:498-507.

2. Kobayashi M, Shinohara M, Sakoh C, Kataolsa M, Shimizu S. Lactone-ring-cleaving enzyme: genetic analysis, novel RNA editing, and evolutionary implications. Proc Natl Acad Sci USA 1998;95:12787-92.

3. Ng CJ, Wadleigh DJ, Gangopadhyay A, Hama S, Grijalva VR, Navab M, et al. Paraoxonase-2 is a ubiquitously expressed protein with antioxidant properties and is capable of preventing cell-mediated oxidative modification of low density lipoprotein. J Biol Chem 2001;276: 44444-9.

4. Reddy ST, Wadleigh DJ, Grijalva V, Ng C, Hama S, Gangopadhyay $A$, et al. Human paraoxonase-3 is an HDLassociated enzyme with biological activity similar to paraoxonase-1 protein but is not regulated by oxidized lipids. Arterioscler Thromb Vasc Biol 2001;21:542-7.

5. Blatter M-C, James RW, Messmer S, Barja F, Pometta D. Identification of a distinct human high-density lipoprotein subspecies defined by a lipoprotein-associated protein, K-45. Identity of K-45 with paraoxonase. Eur J Biochem 1993;211:871-9.

6. Deakin S, Leviev I, Gomaraschi M, Calabresi L, Franceschini G, James RW. Enzymatically active paraoxonase-1 is located at the external membrane of producing cells and released by a high affinity, saturable, desorption mechanism. J Biol Chem 2002;277:4301-8.

7. Mazur A. An enzyme in animal tissues capable of hydrolysing the phosphorus-fluorine bond of alkyl fluorophosphates. J Biol Chem 1946;164:271-89.

8. Aldridge WN, Reiner E. Serum esterase 1. Two types of esterase ( $A$ and $B$ ) hydrolysing p-nitrophenyl acetate, propionate and butyrate, and a method for their determination. Biochem J 1953;53:227-9.

9. Costa LG, Cole TB, Jarvik GP, Furlong CE. Functional genomic of the paraoxonase (PON1) polymorphisms: effects on pesticide sensitivity, cardiovascular disease, and drug metabolism. Annu Rev Med 2003;54:371-92.

10. La Du BN. Human serum paraoxonase/arylesterase. In: Kalow W, editor. Pharmacogenetics of drug metabolism. New York: Pergamon Press, 1992:51-91.

11. Mackness MI, Thompson HM, Hardy AR, Walker CH. Distinction between ' $A$ '-esterases and arylesterases. Biochem J 1987;245:293-6.

12. Adkins S, Gan KN, Mody M, La Du BN. Molecular basis for the polymorphic forms of human serum paraoxonase/arylesterase: glutamine or arginine at position 191, for the respective A or B allozymes. Am J Hum Genet 1993;52:598-608.

13. Furlong CE, Costa LG, Hassett C, Richter RJ, Sundstrom JA, Adler DA, et al. Human and rabbit paraoxonases: purification, cloning, sequencing, mapping and role of polymorphism in organophosphate detoxification. Chem-Biol Interact 1993;87:35-48.

14. Davies HG, Richter RJ, Keifer M, Broomfield CA, Sowalla $J$, Furlong CE. The effect of the human serum paraoxonase polymorphism is reversed with diazoxon, soman and sarin. Nat Genet $1996 ; 14: 334 \overline{-6 .}$

15. Augustinsson KB. The evolution of esterases. In: Van Thoai N, Roche J, editors. Homologous enzymes and biochemical evolution. New York: Gordon and Breach, 1968:299-311.

16. Ray DE. Chronic effects of low level exposure to anticholinesterases - a mechanistic view. Toxicol Lett 1998;102-103:527-33.

17. Lotti M. The pathogenesis of organophosphate polyneuropathy. Crit Rev Toxicol 1991;21:465-87.

18. Brealey CJ, Walker $\mathrm{CH}$, Baldwin BC. A-esterase activities in relation to the differential toxicity of pirimiphos-methyl to birds and mammals. Pest Sci 1980;11:546-54.

19. Main AR. The role of A-esterase in the acute toxicity of paraoxon, TEPP, and parathion. Can J Biochem Physiol 1956;34:197-216.

20. Li WF, Costa LG, Furlong CE. Serum paraoxonase status: a major factor in determining resistance to organophosphates. J Toxicol Environ Health 1993;40:337-46.

21. Mackness MI, Arrol S, Durrington PN. Paraoxonase prevents accumulation of lipoperoxides in low-density lipoprotein. FEBS Lett 1991;286:152-4. 
22. Chisolm GM, Steinberg D. The oxidative modification hypothesis of atherogenesis: an overview. Free Radic Biol Med 2000;28:1815-26.

23. Aviram M, Rosenblat M, Bisgaier CL, Newton RS, PrimoParma SL, La Du BN. Paraoxonase inhibits high-density lipoprotein oxidation and preserves its functions. A possible peroxidative role for paraoxonase. J Clin Invest 1998;101:1581-90.

24. Watson AD, Berliner JA, Hama SY, La Du BN, Faull KF, Fogelman AM, et al. Protective effect of high density lipoprotein associated paraoxonase. Inhibition of the biological activity of minimally oxidised low density lipoprotein. J Clin Invest 1995;96:2882-91.

25. van Himbergen TM, van Tits LJ, Hectors MP, de Graaf J, Roest M, Stalenhoef AF. Paraoxonase-1 and linoleic acid oxidation in familial hypercholesterolemia. Biochem Biophys Res Commun 2005;333:787-93.

26. Shah PK, Kaul S, Nilsson J, Cercek B. Exploiting the vascular protective effects of high-density lipoprotein and its apolipoproteins: an idea whose time for testing is coming, Part I. Circulation 2001;104:2376-83.

27. Assmann G, Nofer JR. Atheroprotective effects of highdensity lipoproteins. Annu Rev Med 2003;54:321-41.

28. Ahmed Z, Ravandi A, Maguire GF, Emili A, Draganov D, La Du BN, et al. Apolipoprotein A-I promotes the formation of phosphatidylcholine core aldehydes that are hydrolyzed by paraoxonase (PON-1) during high density lipoprotein oxidation with a peroxynitrite donor. J Biol Chem 2001;276:24473-81.

29. Rice-Evans C, Leake D, Bruckdorfer KR, Diplock AT. Practical approaches to low density lipoprotein oxidation: whys, wherefores and pitfalls. Free Radic Res 1996;25: 285-311.

30. Puhl H, Waeg G, Esterbauer H. Methods to determine oxidation of low-density lipoproteins. Methods Enzymol 1994;233:425-41.

31. Mackness MI, Arrol S, Abbot C, Durrington PN. Protection of low-density lipoprotein against oxidative modification by high-density lipoprotein associated paraoxonase. Atherosclerosis 1993;104:129-35.

32. Hedrick CC, Thorpe SR, Fu MX, Harper CM, Yoo J, Kim $\mathrm{SM}$, et al. Glycation impairs high-density lipoprotein function. Diabetologia 2000;43:312-20.

33. Kontush A, Chantepie S, Chapman MJ. Small, dense $\underline{H D L}$ particles exert potent protection of atherogenic LDL against oxidative stress. Arterioscler Thromb Vasc Biol 2003:23:1881-8.

34. Shih DM, Gu L, Hama S, Xia Y-R, Navab M, Fogelman $A M$, et al. Genetic-dietary regulation of serum paraoxonase expression and its role in atherogenesis in a mouse model. J Clin Invest 1996;97:1630-9.

35. Mackness B, Quarck R, Verreth W, Mackness M, Holvoet P. Human paraoxonase-1 overexpression inhibits atherosclerosis in a mouse model of metabolic syndrome. Arterioscler Thromb Vasc Biol 2006;26:1545-50.

36. Shih DM, Gu L, Xia Y-R, Navab M, Li W-F, Hama S, et al. Mice lacking serum paraoxonase are susceptible to organophosphate toxicity and atherosclerosis. Nature 1998;394:284-7.

37. Van Lenten BJ, Hama SY, de Beer FC, Stafforini DM, McIntyre TM, Prescott SM, et al. Anti-inflammatory HDL becomes pro-inflammatory during the acute phase response. J Clin Invest 1995;96:2758-67.

38. Mackness B, Hine D, Liu Y, Mastorikou M, Mackness M. Paraoxonase-1 inhibits oxidised LDL-induced MCP-1 production by endothelial cells. Biochem Biophys Res Commun 2004;318:680-3.

39. Cao H, Girard-Globa A, Berthezene F, Moulin P. Paraoxonase protection of LDL against peroxidation is independent of its esterase activity towards paraoxon and is unaffected by the Q-R genetic polymorphism. J Lipid Res 1999;40:133-9.
40. Sarandol E, Safak O, Dirican M, Uncu G. Oxidizability of apolipoprotein B-containing lipoproteins and serum paraoxonase/arylesterase activities in preeclampsia. Clin Biochem 2004:37:990-6.

41. Rosenblat M, Gaidukov L, Khersonsky O, Vaya J, Oren $\mathrm{R}$, Tawfik DS, et al. The catalytic histidine dyad of high density lipoprotein-associated serum paraoxonase-1 (PON1) is essential for PON1-mediated inhibition of low density lipoprotein oxidation and stimulation of macrophage cholesterol efflux. J Biol Chem 2006;281:7657-65.

42. Shih DM, Xia YR, Wang XP, Miller E, Castellani LW, Subbanagounder $\mathrm{G}$, et al. Combined serum paraoxonase knockout/apolipoprotein E knockout mice exhibit increased lipoprotein oxidation and atherosclerosis. J Biol Chem 2000;275:17527-35.

43. Tward A, Xia YR, Wang XP, Shi YS, Park C, Castellani LW, et al. Decreased atherosclerotic lesion formation in human serum paraoxonase transgenic mice. Circulation 2002;106:484-90.

44. Bradshaw G, Gutierrez A, Miyake JH, Davis KR, Li AC, Glass CK, et al. Facilitated replacement of Kupffer cells expressing a paraoxonase- 1 transgene is essential for ameliorating atherosclerosis in mice. Proc Natl Acad Sci USA 2005;102:11029-34.

45. Mackness $B$, Durrington $P$, McElduff $P$, Yarnell J, Azam $\mathrm{N}$, Watt M, et al. Low paraoxonase activity predicts coronary events in the Caerphilly Prospective Study. Circulation 2003;107:2775-9.

46. Jarvik GP, Rozek LS, Brophy VH, Hatsukami TS, Richter RJ, Schellenberg GD, et al. Paraoxonase (PON1) phenotype is a better predictor of vascular disease than is PON1(192) or PON1(55) genotype. Arterioscler Thromb Vasc Biol 2000;20:2441-7.

47. Leviev I, Righetti A, James RW. Paraoxonase promoter polymorphism $\mathrm{T}(-107) \mathrm{C}$ and relative paraoxonase deficiency as determinants of risk of coronary artery disease. $\mathrm{J}$ Mol Med 2001:79:457-63.

48. Mackness B, Davies GK, Turkie W, Lee E, Roberts DH, Hill $E$, et al. Paraoxonase status in coronary heart disease: are activity and concentration more important than genotype? Arterioscler Thromb Vasc Biol 2001;21: 1451-7.

49. Abbott CA, Mackness MI, Kumar S, Boulton AJ, Durrington PN. Serum paraoxonase activity, concentration, and phenotype distribution in diabetes mellitus and its relationship to serum lipids and lipoproteins. Arterioscler Thromb Vasc Biol 1995;15:1812-18.

50. Sakai T, Matsuura B, Onji M. Serum paraoxonase activity and genotype distribution in Japanese patients with diabetes mellitus. Intern Med 1998;37:581-4.

51. Boemi M, Leviev I, Sirolla C, Pieri C, Marra M, James RW. Serum paraoxonase is reduced in type 1 diabetic patients compared to non-diabetic, first degree relatives; influence on the ability of HDL to protect LDL from oxidation. Atherosclerosis 2001;155:229-35.

52. Boemi M, Sirolla C, Testa R, Cenerelli S, Fumelli $P$, James RW. Smoking is associated with reduced serum levels of the antioxidant enzyme, paraoxonase, in type 2 diabetic patients. Diabet Med 2004;21:423-7.

53. Mackness MI, Harty D, Bhatnagar D, Winocour PH, Arrol $\mathrm{S}$, Ishola $\mathrm{M}$, et al. Serum paraoxonase activity in familial hypercholesterolaemia and insulin-dependent diabetes mellitus. Atherosclerosis 1991;86:193-9.

54. Tomas M, Senti M, Garcia-Faria F, Vila J, Torrents A Covas $\mathrm{M}$, et al. Effect of simvastatin therapy on paraoxonase activity and related lipoproteins in familial hypercholesterolemic patients. Arterioscler Thromb Vasc Biol 2000;20:2113-9.

55. Senti M, Tomas M, Fito M, Weinbrenner T, Covas MI, Sala J, et al. Antioxidant paraoxonase 1 activity in the metabolic syndrome. J Clin Endocrinol Metab 2003; 88:5422-6. 
56. Blatter-Garin M, Kalix B, Morabia A, James RW. Small, dense lipoprotein particles and reduced paraoxonase-1 in patients with the metabolic syndrome. J Clin Endocrinol Metab 2005;90:2264-9.

57. James RW, Leviev I, Righetti A. Smoking is associated with reduced serum paraoxonase activity and concentration in coronary artery disease patients. Circulation 2000; 101:2252-7.

58. Senti M, Aubo C, Tomas M. Differential effects of smoking on myocardial infarction risk according to the $\mathrm{Gln} /$ Arg 192 variants of the human paraoxonase gene. Metabolism 2000;49:557-9.

59. Aviram M, Rosenblat M, Billecke S, Erogul J, Sorenson $\mathrm{R}$, Bisgaier $\mathrm{CL}$, et al. Human serum paraoxonase (PON1) is inactivated by oxidised low density lipoprotein and preserved by antioxidants. Free Radic Biol Med 1999;26:892-904.

60. Jarvik GP, Tsai NT, McKinstry LA, Wani R, Brophy VH, Richter RJ, et al. Vitamin C and E intake is associated with increased paraoxonase activity. Arterioscler Thromb Vasc Biol 2002;22:1329-33.

61. Aviram M, Dornfeld L, Rosenblat M, Volkova N, Kaplan $\mathrm{M}$, Coleman R, et al. Pomegranate juice consumption reduces oxidative stress, atherogenic modifications to $\overline{\mathrm{LDL}}$, and platelet aggregation: studies in humans and in atherosclerotic apolipoprotein E-deficient mice. $\mathrm{Am} \mathrm{J}$ Clin Nutr 2000;71:1062-76.

62. Beer S, Moren X, Ruiz J, James RW. Postprandial modulation of serum paraoxonase activity and concentration in diabetic and non-diabetic subjects. Nutr Metab Cardiovasc Dis 2006. In press, doi 10.1016/j.numecd. 2005.09.005.

63. Deakin S, Moren X, James RW. Very low density lipoproteins provide a vector for secretion of paraoxonase1 from cells. Atherosclerosis 2005;179:17-25.

64. Deakin S, Leviev I, Guernier S, James RW. Simvastatin modulates expression of the PON1 gene and increases serum paraoxonase: a role for sterol regulatory elementbinding protein-2. Arterioscler Thromb Vasc Biol 2003;23:2083-9.

65. Ota K, Suehiro T, Arii K, Ikeda Y, Kumon Y, Osaki F, et al. Effect of pitavastatin on transactivation of human serum paraoxonase 1 gene. Metabolism 2005;54:142-50.

66. Cole TB, Jampsa RL, Walter BJ, Arndt TL, Richter RJ, Shih DM, et al. Expression of human paraoxonase (PON1) during development. Pharmacogenetics 2003;13: 357-64.

67. Furlong CE, Holland N, Richter RJ, Bradman A, Ho A, Eskenazi B. PON1 status of farmworker mothers and children as a predictor of organophosphate sensitivity. Pharmacogenet Genomics 2006;16:183-90.

68. Benmoyal-Segal L, Vander T, Shifman S, Bryk B, Ebstein $\mathrm{RP}$, Marcus EL, et al. Acetylcholinesterase/paraoxonase interactions increase the risk of insecticide-induced Parkinson's disease. FASEB J 2005;19:452-4.

69. Sklan EH, Lowenthal A, Korner M, Ritov Y, Landers DM, Rankinen $T$, et al. Acetylcholinesterase/paraoxonase genotype and expression predict anxiety scores in Health, Risk Factors, Exercise Training, and Genetics study. Proc Natl Acad Sci USA 2004;101:5512-7.

70. Casida JE, Quistad GB. Organophosphate toxicology: safety aspects of nonacetylcholinesterase secondary targets. Chem Res Toxicol 2004;17:983-98.
71. Biggadike K, Angell RM, Burgess CM, Farrell RM, Hancock AP, Harker AJ, et al. Selective plasma hydrolysis of glucocorticoid gamma-lactones and cyclic carbonates by the enzyme paraoxonase: an ideal plasma inactivation mechanism. J Med Chem 2000;43:19-21.

72. Jakubowski H. Calcium-dependent human serum homocysteine thiolactone hydrolase. A protective mechanism against protein n-homocysteinylation. J Biol Chem 2000; 275:3957-62.

73. Khersonsky O, Tawfik DS. Structure-reactivity studies of serum paraoxonase PON1 suggest that its native activity is lactonase. Biochemistry 2005;44:6371-82.

74. Draganov DI, Teiber JF, Speelman A, Osawa Y, Sunahara R, La Du BN. Human paraoxonases (PON1, PON2, and PON3) are lactonases with overlapping and distinct substrate specificities. J Lipid Res 2005;46:1239-47.

75. Serhan CN. Lipoxins and aspirin-triggered 15-epilipoxins are the first lipid mediators of endogenous antiinflammation and resolution. Prostaglandins Leukot Essent Fatty Acids 2005;73:141-62.

76. Libby P. Changing concepts of atherogenesis. J Intern Med 2000;247:349-58.

77. Navab M, Ananthramaiah GM, Reddy ST, Van Lenten BJ, Ansell BJ, Fonarow GC, et al. The oxidation hypothesis of atherogenesis: the role of oxidized phospholipids and HDL. J Lipid Res 2004;45:993-1007.

78. Splaver A, Lamas GA, Hennekens CH. Homocysteine and cardiovascular disease: biological mechanisms, observational epidemiology, and the need for randomized trials. Am Heart J 2004;148:34-40.

79. McCully KS. Chemical pathology of homocysteine. I. Atherogenesis. Ann Clin Lab Sci 1993;23:477-93.

80. Jakubowski H. Molecular basis of homocysteine toxicity in humans. Cell Mol Life Sci 2005;61:470-87.

81. Fuqua C, Parsek MR, Greenberg EP. Regulation of gene expression by cell-to-cell communication: acyl-homoserine lactone quorum sensing. Annu Rev Genet 2001;35: 439-68.

82. Chun CK, Ozer EA, Welsh MJ, Zabner J, Greenberg EP. Inactivation of a Pseudomonas aeruginosa quorumsensing signal by human airway epithelia. Proc Natl Acad Sci USA 2004;101:3587-90.

83. Ozer EA, Pezzulo A, Shih DM, Chun C, Furlong C, Lusis $A J$, et al. Human and murine paraoxonase 1 are host modulators of Pseudomonas aeruginosa quorum-sensing. FEMS Microbiol Lett 2005;253:29-37.

84. Muhlestein JB, Anderson JL. Chronic infection and coronary artery disease. Cardiol Clin 2003;21:333-62.

85. Procopiou PA, Biggadike K, English AF, Farrell RM, Hagger GN, Hancock AP, et al. Novel glucocorticoid antedrugs possessing a 17beta-(gamma-lactone) ring. J Med Chem 2001;44:602-12.

86. Tougou K, Nakamura A, Watanabe S, Okuyama Y, Morino $A$. Paraoxonase has a major role in the hydrolysis of prulifloxacin (NM441), a prodrug of a new antibacterial agent. Drug Metab Dispos 1998;26:355-9.

87. Billecke $S$, Draganov D, Counsell $R$, Stetson P, Watson C, Hsu C, et al. Human serum paraoxonase (PON1) isozymes $\mathrm{Q}$ and $\mathrm{R}$ hydrolyze lactones and cyclic carbonate esters. Drug Metab Dispos 2000;28:1335-42.

Received May 29, 2006, accepted June 20, 2006 